\title{
Modeling of internal diffusion mass transfer during filtration drying of capillary-porous material
}

\author{
Gnativ Z. Ya., Ivashchuk O. S., Hrynchuk Yu. M., Reutskyi V. V., Koval I. Z., Vashkurak Yu. Z. \\ Lviv Polytechnic National University, \\ 12 S. Bandera Str., 79013, Lviv, Ukraine
}

(Received 6 February 2019; Revised 18 November 2019; Accepted 19 November 2019)

\begin{abstract}
The article presents the results of theoretical and experimental studies on the determination of the coefficients of internal diffusion of moisture from capillary-porous materials of plant origin during filtration drying, in particular, beet pulp, a by-product of sugar production. A model based on the solution of the internal diffusion differential equation with the corresponding initial and boundary conditions were used to find the internal diffusion coefficient.

It is established that the process of the beet pulp drying occurs in the second period, and the limiting stage is the intra-diffusion mass transfer.
\end{abstract}

Keywords: filtration drying, beet pulp, hydrodynamic, heat agent, diffusion, modelling.

2010 MSC: $35 \mathrm{C} 10,80 \mathrm{~A} 20$

DOI: $10.23939 / \mathrm{mmc} 2020.01 .022$

\section{Introduction}

It is known that drying is a complex heat and mass transfer process, which is widely used in the final stages of many technological processes, and which depends on the efficiency and quality of the finished product. One of the most important indicators of economic development of the country is the energy intensity of the gross product. Thermal dehydration processes in the world consume about $10 \%$ of all energy produced. In most cases, the drying process uses $2.5-3$ times more energy than is needed to convert the moisture into steam.

Convective drying plants are most commonly used in industry, but analysis of the most common convective drying technologies [1] shows that such energy-efficient drying equipment, environmental regulations, and product safety do not fully meet current requirements. Therefore, we have proposed filtration drying (FD), which is one of the high-intensity, low-temperature and environmentally friendly methods [2-4].

It is known that during drying, it is most difficult to remove the internal moisture since in the internal mass transfer there are about fifteen different types of mass and heat transfer [5]. Therefore, the study of intra-diffusion mass transfer during filtration drying of capillary-porous materials of plant origin is an urgent task. The purpose of our work is to simulate the temperature dependence of intra-diffusion mass transfer during filtration drying of a capillary-porous material of plant origin.

\section{Formulation of the problem}

The sugar industry is one of the most important branches of the food industry in Ukraine. The main product of this huge agro-industrial complex is sugar in the assortment, as well as by-products molasses, beet pulp. In its structure, pulp is a complex colloidal capillary-porous material, its cells and intercellular space are filled with water with a low sugar content. To store and increase the feed value of beet pulp, it is subjected to various technological processes: silage, burgundy drying and granulation of pulp, enrichment with molasses, protein substitutes and others [6,7]. 
The method of determining the internal diffusion coefficient is based on the mathematical solution of the differential equation of convective diffusion. The author [12] developed a mathematical model of the distribution of moisture in a spherical particle during drying, and the coefficients of internal diffusion.

The author [13] investigated the intra-diffusion mass transfer during filtration drying of the "energy" willow. The internal diffusion coefficients are determined based on the differential equation solution:

$$
\frac{\partial w^{c}}{\partial t}=D_{w}\left(\frac{\partial^{2} w^{c}}{\partial r^{2}}+\frac{1}{r} \frac{\partial w^{c}}{\partial r}\right),
$$

were $w^{c}$ is current value of moisture content.

The dependence of the internal diffusion coefficient on the temperature for the crushed "energy" willow was obtained:

$$
D_{w}^{T}=D_{w}^{293}+0.427 \cdot 10^{-10} \cdot(T-293)^{1.5},
$$

were $D_{w^{c}}^{293}=0.64 \cdot 10^{-9} \frac{\mathrm{m}^{2}}{\mathrm{~s}}$.

In [14], to determine the coefficient of internal moisture diffusion, the kinetics of drying a single pellet of raw materials of the production of slag gravel, the pores of which are kinetically equivalent, and a single pellet having the shape of a ball, were investigated. To analyze the process of intradiffusion mass transfer, the coefficient of internal diffusion was determined based on the solution of the following differential equation, which has the form:

$$
\frac{\partial w^{c}}{\partial t}=D_{w^{c}}\left(\frac{\partial^{2} w^{c}}{\partial r^{2}}+\frac{2}{r} \frac{\partial w^{c}}{\partial r}\right) .
$$

The dependence of the internal diffusion coefficient on the temperature of the thermal agent for such a model is:

$$
D_{w}^{T}=D_{w}^{293}+2.5 \cdot 10^{-10} \cdot(T-293) .
$$

Two models, which take into account the unevenness of its structure, of capillary-porous material of plant origin are proposed in the literature [15].

1. A capillary model of a stationary layer, in which the diffusion effects are explained by the different bandwidth and coordination angles of the individual capillaries, which form a continuous network of short capillaries.

2. Model of a stationary layer with closed (unequally accessible) or stagnant zones, the presence of which, when changing the time of the concentration field, causes diffusion effects, which are estimated by the relaxation diffusion coefficients.

However, as the authors point out, the complex configuration of free space between elements of a layer, which in most cases is formed spontaneously, complicates the creation of a theory that could quantitatively estimate the average diffusion coefficient in a layer. In the literature [15], the calculated dependences obtained by different authors are also given to determine the average diffusion coefficient, which in the general case can be represented as a dependence (2) with the corresponding coefficients.

\section{Results of experimental research}

During the filtration, the thermal agent passes through the stationary layer of beet pulp toward the perforated partition. The thermal agent filtered through its porous structure gives off its heat to the wet material and is saturated with moisture vapor. At the outlet of the stationary layer, the thermal agent has a temperature close to that of the wet thermometer throughout the drying period. Its temperature rises only at the end of the drying process asymptotically approaching the temperature of the thermal agent at the inlet to the stationary layer. From which we can conclude that the thermal agent is saturated with moisture during the main drying time and its drying potential is used in full. 
Filtration drying is of a zonal nature and during drying the mass transfer zone moves in the direction of motion of the thermal agent where there is a wet and dry material. Therefore, the mechanism of filtration drying of the dispersed material is as follows:

- mechanical displacement of free moisture, which is held between the pulp particles by the forces of surface tension;

- formation of the mass transfer front;

- simultaneous existence of the first and second drying periods;

- simultaneous existence of dry material, first and second periods and wet material;

- reaching by the front of mass transfer of the perforated partition;

- the existence of only the second drying period.

The authors of [2-4] investigated the dependence of the kinetics of filtration drying of various dispersed materials on the parameters of the thermal agent and the structure of the material layer. However, the results of these works can be used only for a specific material, since the kinetics of the drying process depends on the properties of the dried material.

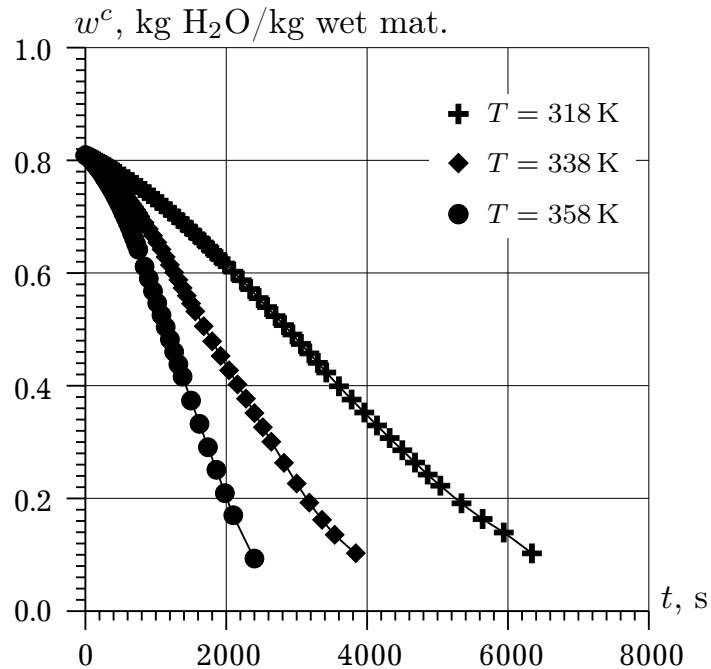

Fig. 1. Changing the humidity of the beet pulp layer in time at different temperatures of thermal agent $\left(v_{0}=1.1 \mathrm{~m} / \mathrm{s} H=80 \mathrm{~mm}\right)$.

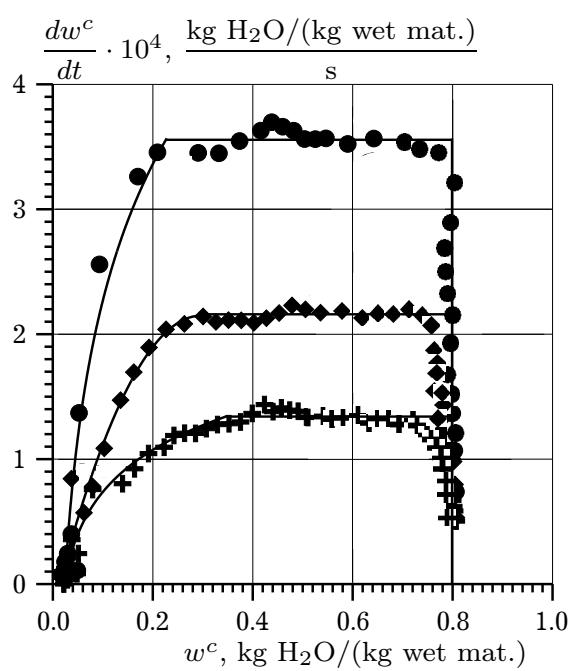

Fig. 3. Speed of filtration drying of pulp at different temperature of thermal agent $\left(v_{0}=1.1 \mathrm{~m} / \mathrm{s}, H=80 \mathrm{~mm}\right)$.

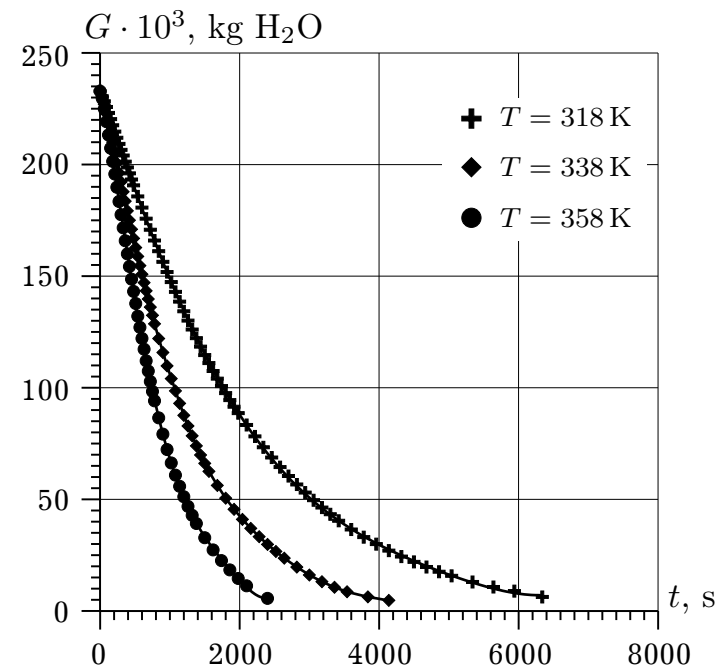

Fig. 2. Dynamics of moisture removal from a layer of beet pulp at different temperatures of the thermal agent.

Since one of the determining parameters affecting the kinetics of the drying process is the temperature of the thermal agent, therefore, we investigated its effect in the range of temperature changes from 318 to $358 \mathrm{~K}$ at the speed of movement of the thermal agent (air) $v_{0}=1.1 \mathrm{~m} / \mathrm{s}$, and height of stationary layer of capillary-porous material of plant origin $H=80 \mathrm{~mm}$ (Fig. 1). Analyzing the influence of the drying temperature on the moisture content of the material (Fig. 1), it is seen that with increasing temperature the slope of the slope of the straight section of the kinetic curves increases and decreases the drying time, this is explained by the increase in the drying potential of the thermal agent, as well as the increase in the coefficient of the internal factor.

In Fig. 2, we observe that with increasing temperature of the thermal agent, the intensity of moisture removal from the material layer increases. This phenomenon is 
explained by the increase in the magnitude of the drying potential of the thermal agent, the increase in the coefficients of heat transfer, as well as the amount of heat brought into the layer with the thermal agent, respectively.

Of great practical importance are the graphical dependences of drying rate on time, which allow to determine the energy costs of the process and to choose the rational drying mode, which are widely used in the industry when designing drying machines.

In Fig. 3, a graphical dependence of the drying rate of pulp $\frac{d w^{c}}{d t}=f\left(w^{c}\right)$ depending on the humidity is shown. As can be seen from Fig. 3, the rate of filtration drying increases with increasing temperature of the thermal agent, since an increase in temperature leads to an increase in the drying potential of the thermal agent and an increase in the internal diffusion coefficients of moisture from the center of the pulp particles to its surface. Also the analysis of Fig. 3 shows that at low temperatures of the thermal agent $(318-328 \mathrm{~K})$, the warm-up period is absent due to the small temperature difference between the wet material and the thermal agent.

\section{Mathematical modeling}

It is known that the coefficient of internal moisture mass transfer is a function of two parameters: the moisture gradient and the temperature gradient [12]. Under the same conditions, the difference between the internal moisture content and the temperature factor will be crucial in determining the internal diffusion coefficient $\widetilde{D}_{w^{c}}^{t}$. The method for determining the internal diffusion coefficient $\widetilde{D}_{w^{c}}^{t}$ is based on the mathematical solution of the internal diffusion differential equation. To describe the process of diffusion of moisture in the material layer, we accept the following assumptions:

- each particle in the layer is evenly washed with a thermal agent;

- the values of the moisture content on the surface of the particle correspond to the values of the moisture content of the thermal agent;

- the initial moisture is evenly distributed throughout the volume of the particle.

For particles of cylindrical shape of finite size, given the above assumptions, the problem is reduced to an initial-boundary-value problem with boundary conditions of the first kind, when the moisture content $w^{c}$ is a function of three variables (time $t$, radius $r$ and coordinates $z$ ), and the diffusion equation is presented in the form [13]:

$$
\frac{\partial w^{c}}{\partial t}=D_{w^{c}}\left(\frac{\partial^{2} w^{c}}{\partial r^{2}}+\frac{1}{r} \frac{\partial w^{c}}{\partial r}+\frac{\partial^{2} w^{c}}{\partial z^{2}}\right),
$$

where $D_{w^{c}}$ is internal diffusion coefficient, $\mathrm{m}^{2} / \mathrm{s}$; defined $r, R$ are the radii of the particle changing and outer respectively, $\mathrm{m} ; l$ is half the length of the particle, $\mathrm{m} ; w^{c}, w_{p}^{c}, w_{n}^{c}$ are changing, equilibrium and initial moisture content of the material, respectively, $\mathrm{kg} \mathrm{H}_{2} \mathrm{O} / \mathrm{kg}$ dry mat.

Area of change: $t \in(0,+\infty), r \in(0, R), z \in(-l, l)(\tau>0,0<r<R,-l<z<+l)$

$$
\left\{\begin{array}{l}
w^{c}(r, z, 0)=w_{n}^{c}, \\
w^{c}(r,-l-0, t)=w_{p}^{c}, \\
w^{c}(r,+l+0, t)=w_{p}^{c} \\
w^{c}(R+0, z, t)=w_{p}^{c}
\end{array}\right.
$$

Then the solution of equation (5) with boundary conditions (6), with respect to the deepening of the evaporation zone of the moisture (the boundary between the separation of vapor-moisture in the capillaries of the wet material) will have the form [18]:

$$
\frac{w^{c}-w_{p}}{w_{n}^{c}-w_{p}}=\sum_{n=1}^{\infty} \sum_{m=1}^{\infty} A_{n} A_{m} J_{0}\left(\mu_{n} \frac{r}{R}\right) \cos \left(\mu_{n} \frac{z}{l}\right) \exp \left\{-\left(\mu_{n}^{2}+\mu_{m}^{2} K_{l}^{2}\right) F_{o}\right\},
$$


where $w$ is changing value of moisture content, $w$ is equilibrium value, $A_{n}=\frac{2}{\mu_{n} J_{1}\left(\mu_{n}\right)}, \mu_{n}=(2 n-1) \frac{\pi}{2}$ is Bessel root functions of the first rate of zero order, $A_{m}=(-1)^{m+1} \frac{2}{\mu_{m}}, \mu_{m}=(2 m-1) \frac{\pi}{2}$.

Introduce dimensionless variables: $K_{l}=R / l, F_{O}=D_{w} \tau / R^{2}$ is the Fourier number.

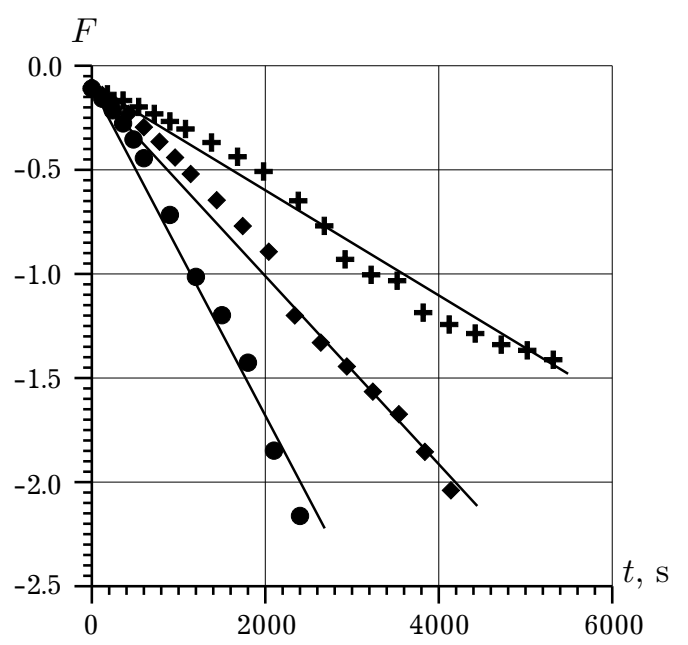

Fig. 4. Dependence $F$ on the time of filtration drying of beet pulp at different temperatures of the thermal agent.

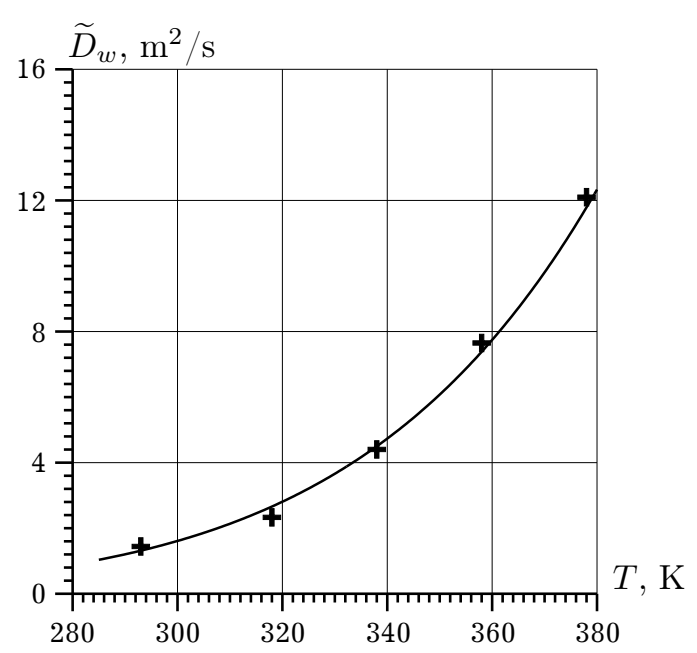

Fig. 5. Dependence of the internal diffusion coefficient on the temperature of the thermal agent.

The solution of Eq. (5) with boundary conditions (6), regarding the change in the average moisture content of beet pulp particles by volume of the particle will look like:

$$
\frac{w^{c}-w_{p}}{w_{n}^{c}-w_{p}}=\sum_{n=1}^{\infty} \sum_{m=1}^{\infty} B_{n} B_{m} \exp \left\{-\left(\mu_{n}^{2}+\mu_{m}^{2} K_{l}^{2}\right) F_{o}\right\},
$$

where $B_{n}=4 / \mu_{n}^{2}, B_{m}=4 / \mu_{m}^{2}$.

To simplify the calculations by highlighting the regular mode, we will use only the first roots of the characteristic equation.

Let us denote $\frac{w^{c}-w_{p}}{w_{n}^{c}-w_{p}}=\Delta w^{c}$ and prologify the dependence (8) with the following simplifications:

$$
\ln \Delta w^{c}=\ln \left(B_{n} B_{m}\right)-\left(\mu_{n}^{2}+\mu_{m}^{2} K_{l}^{2}\right) F_{O}
$$

or

$$
-\frac{\ln \left(\Delta w^{c} /\left(B_{n} B_{m}\right)\right)}{\mu_{n}^{2}+\mu_{m}^{2} K_{l}^{2}}=F_{O}
$$

denote $-\frac{\ln \left(\Delta w^{c} /\left(B_{n} B_{m}\right)\right)}{\mu_{n}^{2}+\mu_{m}^{2} K_{l}^{2}}=F$ and present it as a graphical dependency $F=f(\tau)$ (Fig. 4).

Analyzing Fig. 4 shows that the experimental data can be approximated by a straight line and by the tangent of the angle of inclination of the straight line to the abscissa axis, the internal diffusion coefficient can be determined $D_{w^{c}}^{T}$, or:

$$
D_{w}=\tan \alpha \cdot R^{2}
$$

Let us represent the value of the internal diffusion coefficient as:

$$
\widetilde{D}_{w^{c}}^{T}=D_{w^{c}} \cdot A
$$

where $A$ is dimensionless coefficient $\left(A=10^{-9}\right)$.

In Table 1, the values of the internal diffusion coefficients $\widetilde{D}_{w^{c}}^{T}$ are shown, at different temperatures of the thermal agent $a$ in Fig. 5 data in the form of graphical dependence are presented.

Table 1. The values of the internal diffusion coefficients $\widetilde{D}_{w^{c}}^{T}$ at different temperatures of the thermal agent.

\begin{tabular}{|c|c|c|c|c|c|}
\hline$T, \mathrm{~K}$ & 293 & 318 & 338 & 358 & 378 \\
\hline$\widetilde{D}_{w^{c}}^{T}, \mathrm{~m}^{2} / \mathrm{s}$ & 1.44 & 2.33 & 4.40 & 7.65 & 12.1 \\
\hline
\end{tabular}

From Table 1 and Fig. 5 we see that as the temperature of the thermal agent increases, the value of the internal diffusion coefficient $D_{w}$ from the pulp layer into the environment increases, which does not contradict the physical essence of the process and is well correlated with the literature data obtained by other authors $[6,15]$. In order that the obtained experimental data can be used in practice for other temperatures, Fig. 5 shows the experimentally determined values of the diffusion coefficients depending on the temperature approximated by a power function. 
Then the calculated dependence to determine the internal diffusion coefficient $\widetilde{D}_{w^{c}}^{T}$ in the temperature range $293 \leqslant T \leqslant 380 \mathrm{~K}$, with remembering that $\widetilde{D}_{w^{c}}^{293}=D_{W^{c}}^{293} \cdot A, \widetilde{D}_{w^{c}}^{T}=D_{w}^{T} \cdot A,\left(A=10^{-9}\right)$ can be presented as:

$$
\widetilde{D}_{w^{c}}^{T}=\widetilde{D}_{w^{c}}^{293}+1.48 \cdot(T-293)^{2} \cdot 10^{-3} .
$$

Comparison of the dependence (10) with the analytical dependences given in the technical literature to determine the internal diffusion coefficient $D_{w}$ as a function of temperature indicates that for a biological object the effect of temperature is much greater than for other objects, especially of mineral origin.

\section{Conclusions}

The process of intra-diffusion mass transfer during drying of wet beet pulp is mathematically described. On the basis of the proposed model of internal diffusion, its dependence on temperature was investigated. The calculated dependences (7) and (10) were obtained to determine the coefficient of internal diffusion of moisture from cylindrical particles. The calculated values $D_{w}$ of the internal diffusion coefficient of beet pulp during filtration drying by means of the dependence (7) are in good agreement with the experimentally determined values. Generalized theoretical and experimental studies of the dynamics of heat and mass transfer will allow us to predict for the various productivity and initial parameters of raw materials the required overall dimensions of the equipment and the residence time of the material in the drying zone, which will provide the required quality of the final product.

[1] Burdo O. G., Tersiev S. G., Yarovoy I. I., Borshch A. A. Raw material dewatering electromagnetic technologies. Problems of the regional energetics. 1 (18), 36-41 (2012), (in Russian).

[2] Atamanyuk V., Huzova I., Gnativ Z. Intensification of Drying Process During Activated Carbon Regeneration. Chemistry \& Chemical Technology. 12 (2), 263-271 (2018).

[3] Barna I., Gumnytskyi Y., Atamanyuk V. Intradiffusion Mass Transfer during Drying of Slag Gravel Raw Granule. Chemistry \& Chemical Technology. 7 (4), 461-465 (2013).

[4] Matkivska I., Gumnytskyi Y., Atamanyuk V. Kinetics of Diffusion Mass Transfer during Filtration Drying of Grain Materials. Chemistry \& Chemical Technology. 8 (3), 359-363 (2014).

[5] Frolov V.F. Makrokineticheskij analiz sushki dispersnyh materialov. Sovremennye jenergosberegajushhie teplovye tehnologii (sushka i termovlazhnostnaja obrabotka materialov), I Mezhdunar. nauchnoprakticheskaja konferencija, 25-31 may 2002, Moskva, 2, 7-17 (2002), (in Russian).

[6] Fadel J. G., DePeters E. J., Arosemena A. Composition and digestibility of beet pulp with and without molasses and dried using three methods. Animal Feed Science and Technology. 86 (1-2), 121-129 (2006).

[7] Slavjanskij A. A. Promyshlennoe proizvodstvo sahara. Moskva, MGUTU imeni K. G. Razumovskogo (2015), (in Russian).

[8] Aksu Z., Isoglu I. A. Use of dried sugar beet pulp for binary biosorption of Gemazol Turquoise Blue-G reactive dye and copper(II) ions: Equilibrium modeling. Chemical Engineering Journal. 127 (1-3), 177188 (2007).

[9] Reddad Z., Gérente C., Andrès Y., Ralet M.-C., Thibault J.-F., Cloirec P. L. Ni(II) and Cu(II) binding properties of native and modified sugar beet pulp. Carbohydrate Polymers. 49 (1), 23-31 (2002).

[10] Castro L., Blázquez M. L., Muñoz J. A., GonzálezF., García-Balboa C., Ballester A. Biosynthesis of gold nanowires using sugar beet pulp. Process Biochemistry. 46 (5), 1076-1082 (2004).

[11] Atamaniuk V. M., Humnytskyi Ya. M. Naukovi osnovy filtratsiinoho sushinnia dyspersnykh materialiv. Lviv, Lviv Polytechnic National University (2013), (in Ukrainian).

[12] Atamaniuk V. M. Hidrodynamika i teplomasoobmin pid chas filtratsiinoho sushinnia dyspersnykh materialiv. DSc Thesis. Lviv (2007), (in Ukrainian).

[13] Mosiuk M. I. Hidrodynamika i teplo masoobmin pid chas sushinnia podribnenoi «enerhetychnoi» verby v statsionarnomu shari. Phd Thesis. Lviv (2012), (in Ukrainian). 
[14] Barna I. R. Hidrodynamika i teplomasoobmin pid chas filtratsiinoho sushinnia syrovynnykh materialiv shlakovoho hraviiu. Phd Thesis. Lviv (2013), (in Ukrainian).

[15] Aerov M. E., Todes O. M. Gidravlicheskie i teplovye osnovy raboty apparatov so stacionarnym i kipjashhim zernistym sloem. Leningrad, Himija (1968), (in Russian).

[16] Atamanyuk V., Gumnitsky Ya. Mass exchange dynamics during second filtration drying period. Chemistry \& Chemical Technology. 3 (2), 129-137 (2009).

[17] Rudobashta S. P., Nuriev N. N. Kinetika nizkotemperaturnoj sushki ozonirovannym vozduhom. Trudy pervoj mezhdunarodnoj nauchno-prakticheskoj konferencii "Sovremennye jenergosberegajushhie teplovye tehnologi (sushka i termovlazhnostnaja obrabotka materialov)": tr. mezhdunarod. nauch.-praktich. konf. MGAU. 4, 56-59 (2002), (in Russian).

[18] Lykov A. V. Teorija teploprovodnosti. Moskva, Vysshaja shkola (1967), (in Russian).

\title{
Моделювання внутрішньодифузійного масоперенесення під час фільтраційного сушіння капілярно-пористого матеріалу
}

Гнатів 3. Я., Іващук О. С., Гринчук Ю. М., Реутський В. В., Коваль І. З., Вашкурак Ю. 3.

\author{
Національний університет "Львівсъка політехніка", \\ вул. С. Бандери, 12, Львів, 79013, Україна
}

\begin{abstract}
У статті представлено теоретичні та експериментальні дослідження щодо визначення коефіцієнтів внутрішньої дифузії вологи із капілярно-пористих матеріалів рослинного походження під час фільтраційного сушіння бурякового жому, побічного продукту цукрового виробництва. Для знаходження коефіцієнта внутрішньої дифузії використана модель, що базується на розв'язку диференційного рівняння внутрішньої дифузії з відповідними початковими та граничними умовами.

Встановлено, що процес сушіння бурякового жому відбувається у другому періоді, а лімітуючою стадією є внутрішньодифузійне масоперенесення.
\end{abstract}

Ключові слова: фільтрачійне сушіння, буряковий жом, гідродинаміка, тепловий агент, дифузія, моделювання. 